\title{
PENERAPAN MODEL PEMBELAJARAN LEARNING CYCLE 5E UNTUK MENINGKATKAN RASA INGIN TAHU DAN PRESTASI BELAJAR SISWA PADA MATERI KESETIMBANGAN KIMIA KELAS XI SEMESTER GANJIL SMA NEGERI 1 TERAS TAHUN PELAJARAN 2015/2016
}

\author{
Rahardian Prihastoto*, Ashadi, dan Haryono \\ Program Studi Pendidikan Kimia, FKIP, Universitas Sebelas Maret, Surakarta, Indonesia \\ *Keperluan korespondensi, telp: 085700072487, email: prihaz.the.ace@gmail.com
}

\begin{abstract}
ABSTRAK
Penelitian ini bertujuan untuk meningkatkan: (1) rasa ingin tahu dan (2) prestasi belajar (sikap sosial, pengetahuan, dan keterampilan) siswa pada materi kesetimbangan kimia dengan menerapkan model pembelajaran Learning Cycle 5E pada kurikulum 2013. Penelitian ini merupakan penelitian tindakan kelas yang terdiri dari dua siklus. Setiap siklus terdiri dari perencanaan tindakan, pelaksanaan tindakan, observasi dan refleksi. Subjek penelitian adalah siswa kelas XI MIA 4 SMA Negeri 1 Teras Tahun Pelajaran 2015/2016. Sumber data berasal dari guru dan siswa. Data diperoleh melalui angket, tes, observasi serta wawancara. Teknik analisis data yang digunakan adalah analisis deskriptif kualitatif. Hasil penelitian menunjukkan bahwa model pembelajaran Learning Cycle $5 E$ dapat meningkatkan prestasi belajar siswa (aspek pengetahuan $47,06 \%$ pada siklus I menjadi $79 \%$ pada siklus II) pada materi kesetimbangan kimia. Rasa ingin tahu siswa telah tercapai pada siklus I dengan persentase sebesar $73,00 \%$. Dari aspek sikap sosial mencapai target, yaitu dengan persentase $81,81 \%$ pada siklus I. Pada aspek keterampilan mencapai $94,12 \%$. Kesimpulan penelitian ini adalah penerapan model pembelajaran Learning Cycle 5E dapat meningkatkan: (1) rasa ingin tahu dan (2) prestasi belajar siswa pada materi kesetimbangan kimia kelas XI MIA 4 SMA Negeri 1 Teras.
\end{abstract}

Kata Kunci : penelitian tindakan kelas, Learning Cycle 5E, rasa ingin tahu, prestasi belajar

\section{PENDAHULUAN}

Sekolah sebagai lembaga pendidikan formal secara sistematis telah merencanakan lingkungan pendidikan yang menyediakan bermacam kesempatan bagi siswanya untuk melakukan berbagai kegiatan belajar, sehingga siswa memperoleh pengalaman pendidikan. Dengan demikian mendorong pertumbuhan serta perkembangan ke arah suatu tujuan yang telah dicitacitakan. Lingkungan tersebut disusun dalam bentuk kurikulum dan metode pengajaran.

Keberhasilan pembelajaran di kelas dapat ditentukan oleh beberapa komponen yaitu kurikulum, guru dan siswa. Keberhasilan pembelajaran juga tergantung pada penggunaan metode pembelajaran yang diterapkan oleh guru dalam pelaksanaan pembelajaran tersebut. Selain itu keberhasilan pembelajaran juga ditunjang oleh sikap disiplin tentu akan sangat berimbas pada prestasi belajar yang dapat dicapai oleh peserta didik sesuai dengan yang diharapkan.

Kurikulum 2013 bertujuan untuk mempersiapkan masyarakat Indonesia agar memiliki kemampuan hidup sebagai pribadi dan warga negara yang beriman, produktif, kreatif, inovatif, dan afektif serta mampu berkontribusi pada kehidupan bermasyarakat, berbangsa, bernegara, dan peradaban dunia. Dalam rangka mewujudkan manusia Indonesia yang beriman, produktif, kreatif, inovatif, dan afektif maka dalam Permendikbud tentang Standar Proses dinyatakan bahwa proses pembelajaran pada 
satuan pendidikan diselenggarakan secara interaktif, inspiratif, menyenangkan, menantang, memotivasi peserta didik untuk berpartisipasi aktif, serta memberikan ruang yang cukup bagi prakarsa, kreativitas, dan kemandirian sesuai dengan bakat, minat, dan perkembangan fisik serta psikologis peserta didik. Pembelajaran diarahkan untuk mendorong peserta didik mencari tahu dari berbagai sumber observasi, mampu merumuskan masalah (menanya) bukan hanya menyelesaikan masalah. Di samping itu pembelajaran diarahkan untuk melatih peserta didik berfikir analitis dalam pengambilan keputusan bukan berfikir mekanistis (rutin) serta mampu bekerjasama dan berkolaborasi dalam menyelesaikan masalah [1].

Kurikulum 2013, pelajaran kimia merupakan salah satu mata pelajaran yang diajarakan pada kurikulum SMA. Mata pelajaran kimia merupakan mata pelajaran wajib bagi siswa yang telah mengambil jurusan IPA. Seiring perubahan kurikulum yang diterapkan di Indonesia maka terjadi perubahan pula terhadap tata cara pengajaran kimia di SMA. Perubahan tersebut terdapat pada sususan materi pembelajaran, konteks pembelajaran kimia yang diperdalam serta pemberian materi yang menuntut siswa untuk aktif dan dominan dalam sistem belajar mengajar.

Mata pelajaran Kimia di SMA/MA mempelajari segala sesuatu tentang zat yang meliputi komposisi, struktur dan sifat, perubahan, dinamika dan energetika zat yang melibatkan keterampilan dan penalaran. Ilmu kimia juga mempelajari tentang zat-zat kimia yang bermanfaat bagi kehidupan manusia. Berbagai peristiwa alam yang ditemukan sehari-hari juga dapat dipelajari di dalam ilmu kimia, tetapi selama ini masih banyak siswa yang mengalami kesulitan dalam memahami dan mengikuti pelajaran kimia. Kesulitan pembelajaran kimia terletak pada kesenjangan yang terjadi antara pemahaman konsep dan penerapan konsep yang ada, sehingga menimbulkan asumsi sulit untuk mempelajari dan mengembangkannya [2].

Berdasarkan hasil observasi dan wawancara yang dilakukan di SMA N 1
Teras yang menerapkan kurikulum 2013 pada Agustus 2015, metode yang sering digunakan saat pembelajaran Kimia adalah metode konvensional dengan ceramah. Hal ini disebabkan guru masih perlu penyesuaian terhadap kurikulum 2013 yang tergolong masih baru. Salah satu penyesuaian yang terjadi yaitu pada penerapan lima poin penting dalam Kurikulum 2013 (mengamati, menanya, mengumpulkan data, mengasosiasi, dan mengomunikasi) yang memerlukan banyak waktu dan pada sistem evaluasi siswa yang dirasa tergolong rumit. Metode pembelajaran dengan ceramah cenderung monoton, guru menyampaikan materi secara ceramah dan mengharapkan peserta didik mendengarkan, mencatat, dan paham terhadap materi yang disampaikan.

Dari hasil wawancara dengan guru mata pelajaran kimia pada Agustus 2015, siswa mengalami kesulitan dalam materi kesetimbangan kimia. Kesulitan yang dialami siswa yaitu dalam memahami konsep-konsep dan juga merupakan materi yang bersifat hitungan, ataupun karena memang sejak awal kurang tertarik dengan pelajaran kimia. Belum nampak adanya variasi metode pembelajaran maupun inovasi-inovasi dalam metode maupun media pembelajaran, meskipun guru sempat memberikan kesempatan kepada siswa untuk berdiskusi. Saat guru sedang menjelaskan materi dengan metode ceramah, siswa cenderung diam dan hampir tidak ada siswa yang bertanya ketika dijelaskan oleh guru meskipun guru memberikan kesempatan. Hal ini mengindikasikan bahwa rasa ingin tahu siswa masih tergolong rendah.

Permasalahan-permasalahan yang terdapat pada SMA Negeri 1 Teras Boyolali tersebut, dapat diidentifikasi sebagai berikut: 1) Metode ceramah cenderung membuat pembelajaran yang agak pasif bagi siswa, karena pembelajaran masih berpusat pada guru. 2) Belum diterapkannya secara maksimal Kurikulum 2013 di kelas, karena justru memakan waktu yang banyak serta jumlah konsep pembelajaran hanya sedikit yang tersampaikan. 3) Siswa tidak ada yang bertanya pada saat jalannya 
proses pembelajaran, dan siswa tidak ada yang menjawab pertanyaan tanpa ditunjuk oleh guru, sehingga siswa dapat digolongkan memiliki rasa ingin tahu yang masih rendah. 4) Salah satu materi pelajaran yang masih sulit dipahami dan dikuasai siswa adalah materi kesetimbangan kimia, hal ini mengakibatkan kurang maksimalnya kualitas hasil belajar kimia dari ranah pengetahuan.

Rasa ingin tahu penting untuk dimiliki setiap siswa karena membuat siswa menjadi pengamat yang aktif. Salah satu cara belajar yang baik adalah dengan cara mengamati. Rasa ingin tahu membuat siswa lebih peka dalam mengamati berbagai fenomena di sekitarnya yang berarti siswa akan belajar lebih banyak. selain itu rasa ingin tahu membuat pikiran siswa menjadi aktif. Dimana pikiran yang aktif merupakan modal belajar yang baik.

Untuk memperbaiki kualitas proses belajar kimia di kelas itu, perlu dicari suatu desain atau program pembelajaran yang dapat membuat siswa terlibat aktif dan memiliki rasa ingin tahu terhadap ilmu kimia. Sebagai tindak lanjut guna mengatasi permasalahan yang terjadi maka perlu dilakukan penelitian tindakan (action research) yang berorientasi pada perbaikan kualitas pembelajaran melalui sebuah Penelitian Tindakan Kelas (PTK) yang menurut Maharani (2014) bertujuan untuk memperbaiki kualitas proses pembelajaran dengan sasaran akhir memperbaiki hasil belajar siswa, sehingga PTK mempunyai manfaat yang sangat besar dalam meningkatkan kualitas pembelajaran di kelas.

Salah satu model pembelajaran yang diusulkan oleh peneliti adalah model pembelajaran Learning Cycle 5E. Model pembelajaran ini mempunyai karakteristik konstruktivis dimana pengetahuan tidak dapat ditransfer begitu saja dari pikiran guru ke pikiran siswa. Artinya siswa harus aktif secara mental membangun struktur pengetahuannya berdasarkan kematangan kognitif yang dimilikinya [3]. Model pembelajaran Learning Cycle 5E terdiri dari 5 tahap penyajian pembelajaran yaitu : 1) Engage (Libatkan), 2) Explore (Eksplorasi), 3) Explain (Jelaskan), 4)
Elaborate (Kembangkan), 5) Evaluate (Lakukan Evaluasi) [4], [5], [6].

Berdasarkan uraian diatas maka peneliti tertarik untuk melakukan penelitian dengan judul: "Penerapan Model Pembelajaran Learning Cycle 5E Untuk Meningkatkan Rasa Ingin Tahu dan Prestasi Belajar Siswa Pada Materi Kesetimbangan Kimia (Studi Kasus pada Kelas XI Semester Ganjil SMA Negeri 1 Teras Tahun Pelajaran 2015/2016".

\section{METODE PENELITIAN}

Penelitian ini merupakan Penelitian Tindakan Kelas (PTK) yang dilaksanakan dalam dua siklus. PTK merupakan merupakan suatu pencermatan terhadap kegiatan belajar berupa sebuah tindakan dalam sebuah kelas [7].

Subyek penelitian adalah siswa kelas XI MIA 4 SMA Negeri 1 Teras, Boyolali tahun pelajaran 2015/2016. Pemilihan subyek dalam penelitian ini berdasarkan pada nilai ulangan kimia kelas XI MIA 4 masih banyak yang belum tuntas dan kurang aktifnya siswa di kelas pada saat proses pembelajaran. Penggunaan model pembelajaran diharapkan tepat diterapkan dalam kelas XI MIA 4 SMA Negeri 1 Teras. Obyek dalam penelitian tindakan kelas ini adalah rasa ingin tahu dan prestasi belajar siswa.

Data yang dikumpulkan dalam penelitian ini meliputi data informasi tentang keadaan siswa dilihat dari aspek kualitatif dan kuantitatif. Aspek kualitatif berupa data hasil observasi, wawancara, kajian dokumen atau arsip dengan berpedoman pada lembar pengamatan dan pemberian angket yang menggambarkan proses pembelajaran di kelas. Aspek kuantitatif yang dimaksud adalah berupa data penilaian hasil belajar siswa pada materi kesetimbangan kimia yang meliputi aspek pengetahuan, sikap dan keterampilan baik siklus I maupun siklus II.

\section{HASIL DAN PEMBAHASAN}

Rasa ingin tahu adalah minat mencari kebaruan, keterbukaan, terhadap pengalaman baru, menaruh perhatian pada hal-hal atau pengalaman 
baru, melihat berbagai hal atau topik sebagai hal-hal menarik, menjelajah dan berusaha menemukan sesuatu [8]. Rasa ingin tahu adalah sikap dan tindakan yang selalu berupaya untuk mengetahui lebih mendalam dan meluas dari sesuatu yang dipelajarinya, dilihat, dan didengar. Rasa ingin tahu siswa dikembangkan dengan cara menghadapkan siswa pada permasalahan kehidupan sehari-hari yang memacunya untuk berpikir dan kemudian memunculkan pertanyaan dan berusaha untuk mencari solusinya. Rasa ingin tahu merupakan salah satu sikap ilmiah yang harus dikembangkan dalam pembelajaran sains [9].

Jadi, rasa ingin tahu merupakan hasrat untuk mengetahui sesuatu sebagai landasan untuk mencari kebenaran yang pada akhirnya diperoleh pengetahuan. Keingintahuan atau curiosity merupakan salah satu aspek yang bersifat kondisional bagi pengembangan siswa. Dengan rasa ingin tahu yang tinggi, siswa akan selalu ingin tahu segala hal, dia akan selalu bertanya apa, mengapa dan bagaimana, yang akibatnya timbul pengetahuan ilmiah. Di dalam kelas dia akan selalu sering mengajukan pertanyaan bila diberi kesempatan. Diluar sekolah, siswa yang termasuk kategori ini kelihatan selalu menginginkan sesuatu yang lebih dari apa yang sudah diterima. Anak yang memiliki keingintahuan tinggi menanggapi secara positif terhadap pelajaran yang diberikan oleh gurunya.

Pengukuran rasa ingin tahu siswa didasarkan pada perolehan skor dalam pengisian angket dan lembar observasi, skor tinggi menunjukkan siswa tersebut mempunyai rasa ingin tahu yang tinggi begitu juga sebaliknya. Dalam angket terdapat pertanyaan yang bersifat positif dan negatif, kemudian siswa sebagai responden memberikan respon sesuai dengan keadaan pribadi. Indikator rasa ingin tahu dibuat berdasarkan definisi para ahli diatas.

Salah satu indikator dalam penelitian ini yaitu rasa ingin tahu siswa. Rasa ingin tahu siswa dalam proses pembelajaran ini diukur melalui angket dan observasi yang dilaksanakan di akhir siklus I. Angket dan observasi yang digunakan dibuat berdasarkan indikator rasa ingin tahu yang terdiri dari (1) Bereaksi positif terhadap lingkungan belajar, (2) Ingin tahu lebih banyak tentang permasalahan-permasalahan baru, (3) Keinginan untuk memperdalam materi, (4) Antusias pada proses sains, (5) Menanyakan langkah-langkah kegiatan, (6) Bertanya atau membaca sumber di luar buku teks tentang materi yang terkait dengan pelajaran, (7) Bertanya tentang sesuatu yang terkait dengan materi pelajaran tetapi diluar yang dibahas di kelas.

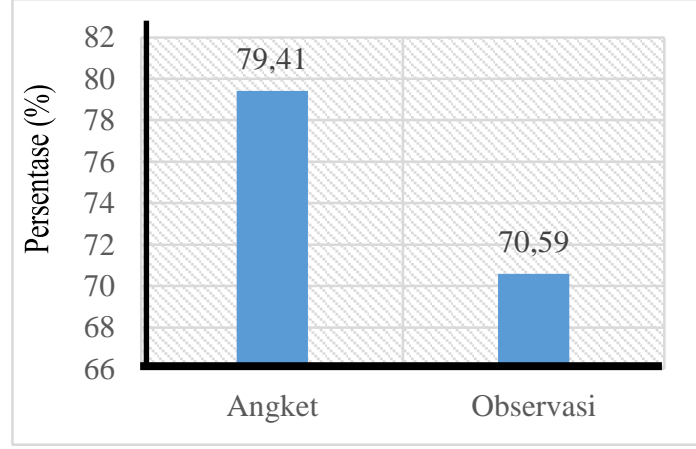

Gambar 1. Histogram Ketercapaian Rasa Ingin Tahu Siswa Siklus I

Hasil akhir penilaian rasa ingin tahu siswa didasarkan pada nilai optimum baik dari hasil angket maupun hasil observasi. Hasil dari perhitungan nilai rasa ingin siswa kelas XI MIA 4 pada siklus I dirangkum dalam Histogram ketercapaian rasa ingin tahu siswa melalui Gambar 1.

Berdasarkan hasil pada Gambar 1 menunjukkan bahwa melalui angket ataupun observasi, rasa ingin tahu siswa telah tercapai, yaitu melebihi target $65 \%$. Sehingga tidak dilakukan pengukuran kembali di siklus II. Hal ini disebabkan oleh model pembelajaran yang diterapkan yaitu Learning Cycle $5 E$ karena Model pembelajaran ini terdiri dari 5 tahap penyajian pembelajaran yaitu : 1) Engage (Libatkan), 2) Explore (Eksplorasi), 3) Explain (Jelaskan), 4) Elaborate (Kembangkan), 5) Evaluate (Lakukan Evaluasi) yang menyebabkan rasa ingin tahu meningkat.

Prestasi belajar aspek pengetahuan dilaksanakan pada siklus I dan II. Instrumen yang digunakan sebagai alat 
evaluasi yaitu soal tes obyektif terdiri dari 26 soal pada siklus 1 dan 18 soal pada siklus II. Histogram persentase ketuntasan aspek pengetahuan siklus I dan siklus II ditunjukkan pada Gambar 2 berikut ini.

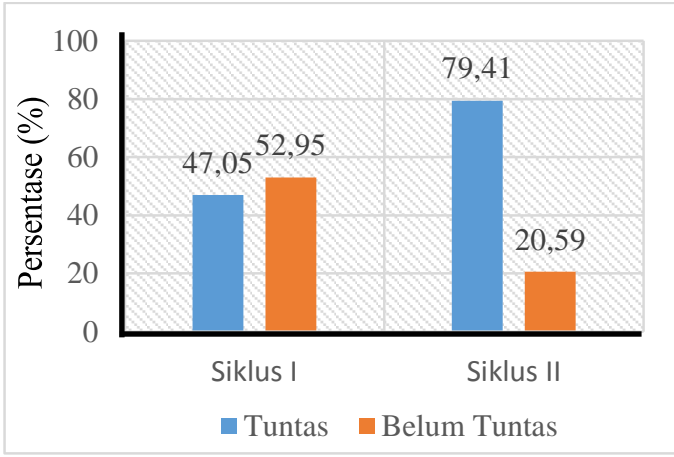

Gambar 2. Histogram Persentase Ketuntasan Aspek Pengetahuan Siklus I dan Siklus II

Hasil tes aspek pengetahuan siklus I menyatakan bahwa siswa yang telah mencapai ketuntasan belajar 16 dari 34 siswa di kelas XI MIA 4 atau $47,06 \%$ dan 18 siswa dari 34 siswa di kelas XI MIA 4 atau $52,94 \%$ dinyatakan belum tuntas. Persentase ini belum mencapai target yang telah ditentukan yaitu $60 \%$. Hasil tes aspek pengetahuan siklus II menyatakan bahwa jumlah siswa yang telah tuntas sebanyak 27 siswa dengan persentase ketuntasan sebesar $79,41 \%$, sedangkan siswa yang belum tuntas sebanyak 7 siswa atau $20,58 \%$.

Kontribusi beberapa siswa yang sudah tuntas sangat besar terhadap keberhasilan kelompok. Materi yang disampaikan difokuskan pada materi yang belum dipahami siswa, sehingga siswa semakin memahami materi pelajaran.

Pada prestasi belajar aspek sikap siswa terhadap pembelajaran, penilaian aspek sikap siswa meliputi sikap sosial (disiplin, jujur, tanggunngjawab, kerjasama, dan toleransi) dilakukan melalui 2 cara yaitu angket penilaian teman sejawat dan angket penilaian diri di akhir siklus. Dari metode-metode ini dilakukan untuk mendapatkan nilai akhir untuk aspek sikap siswa. Berdasarkan hasil analisis, ketuntasan aspek sikap pada siklus I langsung mencapai 100\%, yang berarti telah mengalami target ketercapaian yaitu $75 \%$. Sehingga tidak perlu dilakukan kembali pada siklus II.

Selain penilaian aspek rasa ingin tahu siswa, aspek sikap sosial siswa, dan aspek pengetahuan siswa, peneliti juga melakukan aspek keterampilan siswa terhadap pembelajaran. Prestasi belajar aspek keterampilan siswa pada siklus I telah mencapai $88 \%$, yang berarti telah mengalami target ketercapaian yaitu $75 \%$. Sehingga tidak perlu dilakukan kembali pada siklus II.

Pembelajaran dengan model Learning Cycle 5E merupakan model pembelajaran yang berpusat kepada siswa, dimana siswa secara kelompok menyelesaikan permasalahan dalam pembelajaran kimia. Proses pembelajaran didominasi oleh kegiatan siswa, sehingga guru hanya membimbing dan memfasilitasi setiap kelompok untuk menyelesaikan permasalahan dalam soal diskusi kelompok.

Suatu penelitian tindakan kelas dapat dikatakan berhasil apabila masingmasing indikator yang diukur telah mencapai target yang telah ditetapkan. Penelitian ini dapat dikatakan berhasil karena masing-masing indikator proses dan prestasi belajar siswa yang diukur telah mencapai target yang ditetapkan. Dari hasil tindakan, pengamatan dan pembahasan dapat ditarik kesimpulan bahwa penerapan model pembelajaran Learning Cycle 5E dapat meningkatkan rasa ingin tahu dan prestasi belajar pada materi kesetimbangan kimia siswa kelas XI MIA 4 SMA Negeri 1 Teras Tahun Pelajaran 2015/2016.

\section{KESIMPULAN}

Berdasarkan hasil penelitian yang telah dilakukan, maka dapat diambil kesimpulan bahwa, pembelajaran model Learning Cycle 5E dapat meningkatkan rasa ingin tahu siswa pada materi kesetimbangan kimia kelas XI MIA 4 SMA Negeri 1 Teras tahun ajaran 2015/2016. Hal ini dapat dilihat berdasarkan hasil pelaksanaan tindakan pada siklus I. Persentase siswa dengan kategori rasa ingin tahu pada siklus I telah mencapai $77,00 \%$. Pembelajaran 
model Learning Cycle $5 E$ dapat meningkatkan prestasi belajar siswa pada materi kesetimbangan kimia kelas XI MIA 4 SMA Negeri 1 Teras tahun ajaran 2015/2016. Dalam penelitian ini prestasi belajar mencakup 3 aspek yaitu, aspek pengetahuan, aspek sikap, dan aspek keterampilan. Prestasi belajar aspek pengetahuan pada siklus I hanya mencapai $47,06 \%$ dan dapat meningkat pada siklus II menjadi 79,04\%. Prestasi belajar aspek sikap pada siklus I telah mencapai sebesar $81,81 \%$. Prestasi belajar aspek keterampilan pada siklus I telah mencapai $94,12 \%$.

\section{DAFTAR RUJUKAN}

[1] Kementerian Pendidikan Nasional. (2010). Pengembangan Pendidikan Budaya dan Karakter Bangsa. Pedoman Sekolah. Jakarta: Badan Penelitian dan Pengembangan Pusat Kurikulum.

[2] Sugiyono. (2013). Statistika untuk Penelitian. Bandung: Penerbit Alfabeta.

[3] Suyono \& Hariyanto. (2014). Belajar dan Pembelajaran Teori dan Konsep Dasar. Bandung: PT Remaja Rosdakarya.

[4] Warsono \& Hariyanto. (2012). Pembelajaran Aktif Teori dan Asesmen. Bandung: PT Remaja Rosdakarya.
[5] Cynthia, S.D., Mulyani, Bakti., Utami, Budi. (2013). Penerapan Siklus Belajar 5E (Learning Cycle $5 E$ ) Dengan Penilaian Portofolio Untuk Meningkatkan Kualitas Proses Dan Hasil Belajar Pada Materi Kelarutan Dan Hasil Kali Kelarutan Siswa Kelas XI IPA 2 SMA Negeri 1 Kartasura Tahun Pelajaran 2011/2012. Jurnal Pendidikan Kimia, 2(1), 1-6.

[6] Listyotami, M.K. (2011). Upaya Meningkatkan Kemampuan Koneksi Matematika Siswa Kelas VII A SMP N 15 Yogyakarta melalui Model Pembelajaran Learning Cycle " $5 E$ ". Universitas Negeri Yogyakarta: SKRIPSI

[7] Arikunto, S., Suhardjono \& Supardi. (2011). Strategi Menyusun Penelitian Tindakan Kelas. Jakarta: Andi Offset.

[8] Raka, G. (2011). Pendidikan Karakter di Sekolah. Jakarta: PT. Elex Media Komputindo.

[9] Anwar, H. (2009). Penilaian Sikap Ilmiah dalam Pembelajaran Sains. Jurnal Pelangi IImu, 2(5), 103-113. 